\title{
RESEARCH
}

\section{Enabling citizens' Right to the Smart City through the co-creation of digital platforms}

\author{
Els M. Leclercq ${ }^{1 *}$ (D) and Emiel A. Rijshouwer ${ }^{2}$
}

\section{${ }^{*}$ Correspondence:}

e.m.leclercq@tudelft.nl

${ }^{1}$ Faculty of Architecture and the Built Environment,

TU Delft, Delft, The

Netherlands

Full list of author information is available at the end of the article

\begin{abstract}
In response to increasingly deterministic and all-encompassing implementation of smart city technologies, scholars and activists plea for policies and initiatives to support citizens' democratic 'Right to the Smart City.' Although it is common for government officials and technology companies to make an effort to support citizen participation in smart city development, the question is how this works in practice. The authors engaged in a series of three participatory action research projects with the aim to support citizens"'Right to the Smart City'through the development and use of digital platforms. We find that, although (the processes of co-creatively developing) these platforms do actively address citizens' engagement, empowerment and emancipation in smart city development, their contribution to provide participants with the opportunity to actually and sustainably reframe, reimagine and remake the smart city in a way that benefits them and their communities, is fairly limited. We conclude that time and budget constraints, entrenched technocratic beliefs, as well as vested - traditional - and imbalanced power relationships and divergent views, concerns and objectives prohibit citizens"'Right to the Smart City.' Hence, our plea for 'Governance Beyond Participation:' city making processes that do not perceive citizens as participants or clients, but as valued and trustworthy collaborators in the development and the governance of public space.
\end{abstract}

Keywords: Smart cities, Right to the city, Citizen participation, Empowerment, Engagement, Emancipation, Governance

\section{Policy and practice recommendations}

The following recommendations should be considered when enabling citizens' Right to the Smart City through digital platforms:

1. Provide an environment of 'openness', which means allowing participants to reframe the initiative around their concerns and desires creating flexible, iterative and dynamic, rather than fixed and static processes.

2. Support those involved to articulate and effectuate their political hopes and aspirations for future city life.

3. Grant citizens (and other stakeholders) decision-maker positions. rial. If material is not included in the article's Creative Commons licence and your intended use is not permitted by statutory regulation or exceeds the permitted use, you will need to obtain permission directly from the copyright holder. To view a copy of this licence, visit http:// creativecommons.org/licenses/by/4.0/. 
4. Be specifically and actively open and inviting to all citizens, and specifically to minorities and the disenfranchised. This could, amongst others, be facilitated through levelling the playing field through:
a. providing a shared knowledge base;
b. supporting the development and enhancement of citizens' data literacy; and
c. efforts to systematically overcome power imbalances.

5. Strive for the implementation, safeguarding and maintenance of principles of 'technological sovereignty' and 'data commons' (i.e., the notion that technology should be developed and deployed such that it serves citizens, and that data involved should be owned and governed as a commons).

\section{Introduction}

Increasingly, digital and data-driven 'smart city' technologies are deployed in order to to cope with, among other things, economic crises, climate change, and related issues of resource allocation. The rationale behind this is that real-time analyses of large and combined data sets could help to identify, predict and understand essential urban phenomena and to address them in efficient ways that serve stakeholders' specific needs and concerns (cf., Pentland 2014). Smart city officials and technology corporations claim that these data-driven policies and technologies are developed for citizens to be given an additional opportunity to contribute to city-making processes and therefore potentially enhance the democratic aspect of urban development and governance (De Waal 2011; Morozov and Bria 2018). Critics of this development argue that this kind of technologically informed and enhanced urban development and governance treats citizens as clients or data suppliers, rather than supporting their citizenship and that it contributes to the increasing disciplining of urban life, rather than to more democratic, and sustainable cities (cf., Cardullo et al. 2019; Shelton and Lodato 2019; Vanolo 2014): in the pursuit of ultimate forms of optimization and control, smart city technologies could easily be used to serve (neoliberal) technocratic and solutionist agendas, to favor and cater for specific stakeholders, while excluding minorities and suppressing dissent (Kitchin et al. 2019; Zuboff 2019). In this way smart city technologies might contribute to social and spatial injustice (Fainstein 2011; Soja 2010). This goes against Lefebvre's (1996 [1968]) conceptualization of 'The Right to the City,' which acknowledges an 'absolute' right of all inhabitants to shape the city according to their everyday needs and concerns. Besides the right to appropriate urban space, 'The Right to the City' entails citizens' ability to actively and effectively participate in processes of urban planning, policy-making and decision-making and management through democratic processes (Lefebvre 1996; Harvey 2008; Marcuse 2012).

However, despite the fact that smart city governments and corporations increasingly use a participatory and citizen-centric rhetoric, researchers and activists do not necessarily find that they fundamentally changed the neoliberal and surveilling nature of their projects, or that this contributes to more equal and just cities (cf., Kitchin et al. 2019; Shelton and Lodato 2019). Engelbert et al. (2019) speak of 'tokenism' in this respect, a 
term that Arnstein (1969) used to indicate a situation in which citizens are consulted, or invited to inform top-down urban developments and policy making, but that their 'participation' does not come with any form of actual (decision-making) power or influence. From their study into smart city initiatives in Dublin (Ireland), Cardullo and Kitchin (2018, p. 1) find, for example, little evidence that such initiatives are rooted in "civil, social and political rights and the common good," therefore do not contribute towards citizens' active and productive engagement in city-making. As a consequence, they advocate a normative approach 'to rethink 'smart citizens' and 'smart citizenship' and to remake smart cities if they are to truly become 'citizen-centric"' (cf., Anastasiu 2019; Cardullo 2019; De Waal et al. 2017; Kitchin 2019; Kitchin et al. 2019; Morozov and Bria 2018).

Empirical evidence indicates that open data and open governance initiatives alone are not sufficient to invite and boost citizens' democratic participation and do not necessarily lead to citizen empowerment and their inherent claim on their right to participation in urban projects (Anastasiu 2019; Martin et al. 2018). Kitchin et al. (2019) clearly indicate that the question how citizen-centric smart cities could be stimulated, supported and enabled is still not answered with satisfaction. In this paper we contribute to this research gap by analyzing and reflecting upon the processes and the results of three participatory action research projects, in which we addressed our research question: How could citizens' 'Right to the Smart City' be supported? In these projects citizens, local entrepreneurs, government officials and other stakeholders were actively involved in the development of a digital platform to support their communities' needs and concerns. With the evaluation of these co-creative processes we, firstly, contribute to the academic knowledge on how these processes support citizens' and stakeholders' engagement, empowerment and emancipation in smart city-making. Secondly, we reflect upon how attempts to engage, empower, and emancipate citizens are situated in existing power and governance structures, and upon how these could be reformed in order to support citizens' ability to execute their democratic 'Right to the Smart City.'

\section{'The Right to the Smart City:' theoretical reflection on citizens' engagement, empowerment and emancipation in smart city-making}

The process of city-making has always been a collective effort involving public institutions, private organizations and, to a lesser extent, citizens. In Western cities, the welfare state took up a large role and responsibility in city planning, whereas under neoliberal New Public Management policies the pendulum swung towards the market to tackle urban issues. From the '70's onwards, these parties tended to involve citizens more widely in urban development and governance through participatory processes. These generally took the form of 'tokenism,' varying from informing and consulting citizens, rather than allowing them a decisive say based on equal partnership (Arnstein 1969; Wilcox 1994). In recent years, citizens made attempts to reach for higher sports on Arnstein's ladder. On the one hand they were encouraged by governments, who, in their ambitions to realize the 'participatory society', switched their focus from efficiency and effectiveness towards public values (referred to as New Public Governance, cf. Bekkers and Tummers 2018; Kuitert 2021). Besides their involvement through institutionalized forms (e.g., citizens' initiatives, Living Labs), citizens 
claimed their involvement (e.g., in urban transitions on sustainability initiatives; cf., Lam et al. 2020; Loorbach et al. 2017) and took matters in their own hands through grassroots movements and civic organization (e.g., Occupy Movement, Black Lives Matter; cf., Razsa and Kurnik 2012; Iveson 2013).

The withdrawal of the state from certain aspects of public life, transferring tasks and responsibilities to private actors, including (organized) citizens, and the growing use of digital technology (including social media) are considered opportunities to explore alternative forms of citizens' engagement and democratic participation. This renewed interest of citizens' claim on a 'seat at the table' rather than just being the passive recipient of urban processes, is often rephrased as their 'Right to the City.' With this notion Lefebvre (1996) referred to the right for inhabitants to ownership of the production of urban space. Harvey (2008) conceptualized this right not so much as an individual claim on public resources but as a collective right to shape urban processes. The notion of the 'Right to the Smart city' seeks, in its rhetoric, to contribute to that exact same empowering and emancipatory transformative ideal, as digital and datadriven technologies are believed to enhance the democratic and active engagement of citizens in city-making. Foth (2017) argues that digital technologies are expected to overcome critiques of non-digital practices of placemaking, such as their inability to include representative samples of the target population and to include marginalized and economically threatened communities. Digital technologies are expected to engage a much more diverse group of people on a much larger scale and to facilitate grassroots democratization far beyond traditional practices in which only limited groups of citizens are reached and consulted and in which they could, in many cases, do no more than provide feedback to city governments. As digital tools, in principle, could reach anyone, 'digital placemaking,' Foth argues, is considered a means to actually regard citizens as co-creators in a collaborative form of city-making and to actually grant them the 'Right to the City.' However, this potential of digitally-enhanced citizen engagement is no guarantee for actual increased democratic participation. Shelton and Lodato (2019) find that corporations' discourse of citizen-centricness has not yet resulted in any fundamental changes in the nature and perception of their projects. They developed the ideal types of the 'general' and the 'absent citizen' as a heuristic to demonstrate how citizens are (not) included in smart-city making; i.e., to indicate how a "universal, unspecified and undifferentiated figure of 'the citizen' is discursively deployed in order to justify smart city [policy-making]" (Shelton and Lodato 2019, p. 35), and how 'actual citizens' are not present at the decision-making table, which causes smart citizens' actual problems (concerning social, economic and spatial inequality) to be left unaddressed. Engelbert et al. (2019) conclude, similarly, that institutionally-enforced 'participation' seems to be mainly inviting to compliant 'usual suspects' (tech-savvy and entrepreneurial youngsters) and does not seem to provide 'ordinary' citizens with an opportunity to voice and address their actual and pressing concerns. In this regard, citizens' engagement in digital matters is prone to similar power imbalances, lack of openness, inclusivity, transparency and agency that are characteristic for governmental processes (Iveson 2007; Harvey 2008). Hence the question is how, in concrete cases of city-making, citizens' and stakeholders' 'Right to the Smart City' could be supported. In the following sections we will elaborate 
upon three of the 'Right to the City's' essential aspects: engagement, empowerment and emancipation (cf. Fraser 1990, 2005; Anastasiu 2019; Kitchin 2019; Kitchin et al. 2019).

\section{Engagement}

Anastasiu (2019) claims that participatory city-making would serve as a method to actively engage citizens in claiming and executing their 'Right to the Smart City' in a practical context. In a 'radically democratic' image of a smart city, citizens should have the right and the opportunity to be actively and meaningfully involved in smart citymaking. Sennett (2018) advocates city-making processes that allow for the realization of 'open cities.' Such 'open cities' embrace the open-endedness and the complexity of current and future urban challenges and invite all city participants to collaboratively detect pressing challenges and engage in and experiment with potential solutions, based on stakeholders' values and concerns. Naturally, this vision of an 'open city' in which collaboration is at the heart of city-making, depends not only on people's rights and opportunities to engage in city-making, but on the willingness and ability of actors involved as well (cf. Anastasiu 2019, p. 242); i.e., for public institutions and private organizations to be willing and able to allow for a public sphere that is inclusive to a variety of publics and whereby participation parity and social equality are valued as essential for inclusive and democratic city-making (Fraser 1990).

\section{Empowerment}

Empowerment refers to the notion that citizens have the ability to act (agency) in effective decision-making regarding subjects of their individual or common concern; i.e., that they have and take the opportunity to claim and defend their positions, values and concerns and to generate value for themselves and their communities, in this case in the development and governance of cities (cf. Fung and Wright 2001; Anastasiu 2019). This, among other things, means that all involved should be supported to develop a critical awareness and ability (skills, capacities, resources) to autonomously reflect upon their current situation, and to (re)imagine, propose and realize future alternatives that suit their ideals and concerns. Baack (2015) emphasizes the need for 'empowering intermediaries', which would support and allow those who lack the time and the expert knowledge to be actually actively engaged in processes of smart city-making. In discourses and visions on the 'Right to the Smart City' the concept of technological sovereignty regularly surfaces. This concept refers to the ideal situation in which citizens have the opportunity and the capacity to decide upon how digital and data-driven infrastructure in cities operates, and whom and what ends it serves (Bass and Old 2020; Bria 2016; Morozov and Bria 2018).

\section{Emancipation}

In smart city discourse, citizens are generally considered as a-political consumers or recipients of governmental policies; hence without a political voice that contributes towards the public sphere and fueling public debate. However, citizens are political beings and a central aspect of the 'Right to the City' is that cities should cater for an inclusive and radically democratic public sphere, in which "ordinary people [...] can 
articulate [and effectuate] their [political] hopes and aspirations for future city life" (Kitchin 2019, p. 197; additions by the authors). Fraser (2005) wrote that in order for citizens, and in particular citizens belonging to communities that are less likely to be heard, to be emancipated, they have to be involved within the process of city-making (engagement) and have the ability to act (empowerment). To what degree citizens are emancipated depends on the political and socio-cultural context they are part of, or, more specifically, on whether they have equal opportunities in representation; whether means to participate are equally distributed; and whether their efforts are equally valued (Fraser 2005, p. 305) and whether they are recognized for their contribution (Fraser 1990, 2005; Fainstein 2010).

Reflecting on the above, we conclude that, despite increasingly citizen-centered approaches to smart city-making, these do not necessarily contribute to citizens' 'Right to the Smart City' In order to investigate how citizens' and stakeholders' 'Right to the Smart City' could be enhanced and supported in concrete cases of smart city-making, we should study if and how the development of digital and data-driven practices contribute to their engagement, empowerment and emancipation.

\section{Methodology}

\section{Participatory action research}

Our research on how to support citizens' and stakeholders' 'Right to the Smart City' concerned the study of concrete projects which had the clear aim to actually contribute to stakeholders' engagement, empowerment and emancipation. For this purpose, we engaged in participatory action research. We considered this a relevant scientific method as it concerns "the transformation of power relationships in the direction of greater democracy" (Greenwood and Levin 2007, p. 73). According to Wittmayer and Schäpke (2013, p. 487) "the explicit goal of 'action' is real-life change. [Action-] researchers actively facilitate or participate in [...] learning process[es] and in [...] actual experiments $[. .$.$] while at the same time observing, reflecting and analyzing these actions."$ Doing research in collaboration with relevant stakeholders is characteristic for action research (Beaulieu 2013). Foth and Brynskov (2016, p. 564) consider participatory action research as an indispensable method to "develop new governance infrastructures and practices for civic engagement." They specifically emphasize the design aspect of such participatory processes, as a means "to involve citizens in political debate and action as well as question conventional approaches to political issues" (Foth \& Brynskov, p. 564). The authors argue that design should be applied to support citizens "not only to have a voice but also to appropriate their city in order to take action for change, and to be able to institutionalize and grow communities of socio-technical practice in dosed symbiosis with other systems and institutions" (Foth \& Brynskov, p. 576). They specifically point at their attempts "to give people the tools not only to participate in movements of civic engagement, but to create and use their own in order to establish a DIY (do-it-yourself) mode of fostering civic innovation" and their "overall attempt to formulate a field of practice and research which addresses this organic city making" (Foth \& Brynskov, p. 576; cf., Mulder and Kun 2019). 
In each of the cases we engaged in, we took several roles: we acted as process facilitators as we initiated and organized and structured experiments, discussions, evaluations and design-sessions; we acted as reflective scientists as we aimed to gain scientific knowledge on how to engage, emancipate and empower citizens; we acted as knowledge brokers as we mediated between various perspectives of various stakeholders while trying to make the issues of digitization and datafication relevant and tangible to those involved; and we acted as change agents in the sense that we actively participated in discussions and co-creative design sessions to come up with alternatives for issues and challenges that were identified (Wittmayer and Schäpke 2013). In all of the cases design methods were used to render seemingly intangible topics as digitization and datafication visible and debatable; to support the iterative imagining, testing and discussion of alternative imaginaries based on participants' ideas, values and concerns; and to stimulate (public) debate (cf. Dorst 2019; Jones and Bowes 2017; Mulder and Kun 2019; Mulder and Loorbach 2018). We kept written logs of every meeting's processes, major discussions and outcomes. During and after meetings we interviewed participants in order to assess whether and how they felt they could claim their 'Right to the Smart City'.

\section{Case selection}

In the period January - July 2020 we actively engaged in a series of three design-driven participatory workshops which all had the objective to develop a platform. Platforms are online services to collect, store, analyze, browse, present, access and exchange goods, services, data and information. They are heralded for their democratizing capacities, as, ideally, they provide smart citizens with an equal opportunity to partake in commercial and non-commercial trading and match-making activities, as well as in public and political debates and governing processes. Ideally, they are organized as platform cooperatives, indicating that those involved are having a voice and share in the decisionmaking power. ${ }^{1}$ In their book Ours to hack and to own, Scholz and Schneider (2016) argue that, rather than a recipe or a technological solution, platform cooperativism is a process involving various stakeholders trying to achieve essentially democratic forms of ownership and governance. Hence, to investigate how citizens' 'Right to the Smart City' could be supported in practice, we participated in the co-creative development of three platforms in the Dutch cities of Rotterdam and Amsterdam - which claim to aspire to provide their citizens with an actual say in their smart city projects (Rotterdam 2020; Amsterdam 2019) - and in the evaluation of the processes and the outcomes.

We used Cowley et al.s (2018) types of publicness in smart city initiatives as a criterion to select the cases for this study. From their research into various smart city initiatives, the authors distinguish four types of publicness: political publicness, in which smart city technologies support citizens to be involved in institutional decision-making and deliberation; civic publicness, in which citizens use smart city technologies to actively partake in smart city-making based on their own concerns; entrepreneurial publicness, in which citizens are invited to play an active role in the development of innovative smart city products and services to enhance citizens' lives; and service-user

${ }^{1}$ Although we are well aware of the perverse effects of the platform economy, the scope and topic of this article do not allow us to contribute to that debate and field of research here. 
Table 1 Operationalization of 'Right to the Smart City'-aspects: engagement, empowerment and emancipation

\begin{tabular}{|c|c|c|}
\hline $\begin{array}{l}\text { Characteristics of the } \\
\text { Right to the Smart } \\
\text { City }\end{array}$ & Aspects & Related questions \\
\hline \multirow[t]{3}{*}{ Engagement } & Involvement & $\begin{array}{l}\text { How does the project/process allow for active and mean- } \\
\text { ingful participation? }\end{array}$ \\
\hline & Openness & $\begin{array}{l}\text { How is the project/process open to anyone? Does it support } \\
\text { open-endedness? }\end{array}$ \\
\hline & Inclusivity & Who is invited to participate? \\
\hline \multirow[t]{4}{*}{ Empowerment } & Agency & $\begin{array}{l}\text { How does a process contribute to stakeholders' individual } \\
\text { and/or collective ability to act? }\end{array}$ \\
\hline & Decision-making power & To what degree do stakeholders have a decisive say? \\
\hline & Self-reliance & $\begin{array}{l}\text { How does a process contribute to stakeholders' individual } \\
\text { and/or collective opportunity to generate value according } \\
\text { to their needs and concerns? }\end{array}$ \\
\hline & Empowering intermediaries & $\begin{array}{l}\text { Are there any experts/professionals involved to support } \\
\text { stakeholders' involvement? }\end{array}$ \\
\hline \multirow[t]{3}{*}{ Emancipation } & Representation & $\begin{array}{l}\text { Do all stakeholders have an equal opportunity to be } \\
\text { represented? }\end{array}$ \\
\hline & Recognition & $\begin{array}{l}\text { Are all stakeholders equally recognized and valued for their } \\
\text { efforts? }\end{array}$ \\
\hline & Redistribution & $\begin{array}{l}\text { Are means equally distributed to allow citizens to partici- } \\
\text { pate? }\end{array}$ \\
\hline
\end{tabular}

publicness, in which citizens are seemingly passive users of smart city technologies. We selected cases in all of these categories, except for the latter one, as we study the active engagement and empowerment of citizens.

The first case, 'HalloStrandeiland', is a political platform for democratic city-making. The innovative participatory project DemoS (Democratic Strandeiland) was initiated in 2018 by local citizens as a means to organize and mobilize engaged residents of the Amsterdam IJburg-district in the sustainable development of the adjacent newly developed island, Strandeiland. The second case, 'Homies', is a civic last mile logistics platform. It is the outcome of a design-driven participatory research project that was initiated and hosted by the authors early 2020. In a series of three co-creative workshops in one of the Rotterdam's most deprived areas we developed and tested local and sustainable alternatives regarding issues concerning increases in online shopping and home deliveries. The third case, 'Rotterdam Digitaal', is an entrepreneurial platform. It was initiated by the municipality of Rotterdam during the COVID-crisis as a proactive approach (referred to as a "digital offensive") to support and involve "all Rotterdammers" in developing and deploying digital solutions for social, physical and economic challenges in the face of the emerging platform economy (Rotterdam 2020; KPMG 2020a).

\section{Operationalization}

In the various processes of designing platforms to support citizens' 'Right to the Smart City' the question is how citizens' engagement, empowerment and emancipation could be actively supported. For the various aspects of each of these three concepts we listed related questions (see Table 1 ). 


\section{Findings: co-creating platforms to support citizens' 'Right to the Smart City' HalloStrandeiland}

Strandeiland is part of a series of newly acclaimed islands in the River IJ in Amsterdam. Supported by the city's alderman of New Democracy and the alderman of Sustainability and Spatial Development, inhabitants of an adjacent neighbourhood initiated a project to develop a co-creative and inclusive participatory trajectory for Strandeiland's development process. A participation team was set up, consisting of three inhabitants and three civil servants who collaboratively developed 'HalloStrandeiland.nl', a platform for innovative and participatory city-making. Through this platform a number of initiatives to engage local residents but also the wider Amsterdam population, and hence potential future residents, were undertaken. At the time of writing the community had over 300 members.

\section{Engagement}

The Strandeiland case was initiated by inhabitants of IJburg, who demanded a larger say in the development process of this new island than the current governmental urban design process allowed for. The local government supported their plea to be invited to the planning and decision-making table as equal stakeholders in the process. However, the organizational structure that was eventually drawn up in the formal Participation Plan (Amsterdam 2019) described a traditional client-contractor agreement between the government and the citizens that took a seat in the 'participation team. This traditionally structured agreement caused havoc during the first operational year of this team, because it did not provide the motivated citizens with the opportunity for actual meaningful participation: the topics in which citizen's involvement was asked, were prescribed by the municipality's project officials and not subject of debate. Hence, the topics of participation did not always relate directly to the everyday concerns and needs of the residents. 'HalloStrandeiland.nl' was launched by the participation team with the intention to provide a platform for future residents to connect with each other and to support the participatory decision-making process for Strandeiland, and in particular to reach out to 'non-usual suspects' in order to allow for a more inclusive urban development process. Within the first year of being in operation, the participation team reached, through their local connections and networks, mainly 'usual suspects', active citizens who were already involved in local city-making projects. However, attempts were made to invite a more diverse audience than in traditional public participation processes. One event was for instance held in SET, a large communal living group of 180 people, where refugees live together with Dutch young adults. Both groups are, generally, difficult to engage in citymaking processes but at this event they engaged in sharing their thoughts and concerns regarding the current and future quality of public space. Secondly the platform provided a place where formal documents and reports with regard to this development could be collected and shared. Although the platform was initiated and developed by local citizens, web content that the municipal Strandeiland project leader considered relevant for HalloStrandeiland.nl, had to be approved by authorized civil servants, which marks signs of engagement and transparency but signaled a sense of control and a lack of openness and trust at the same time. 


\section{Empowerment}

The digital platform 'HalloStrandeiland' was developed with the intention to support the participatory decision-making process for Strandeiland. The close collaboration between citizens, civil servants and knowledge institutions was a novel way for the municipality of Amsterdam to experiment with deliberative forms of democracy in order to support citizens' ability to act and their decision-making power within the process of city-making. Although these intentions can be considered laudable, the reality after the first year of working with the participation team was that the decision-making power, ownership and control among citizens within the collaboration process were minimal. The civil servants acted upon their prescribed role as client and became dominant in the decision-making process, in particular in deciding upon the topics and themes that were deemed suitable for asking a wider public's opinion about. Besides that, bringing in local ideas and initiatives based upon the collected stories at the platform lost its priority over the course of the year due to the stringent municipality's project planning process that dictated the content and the pace of the topics dealt with within the participation team, which included the citizens' input in policy documents but ignored the incorporation of local urgencies, such as the lack of quality of open spaces due to a lack of green and abundance of wind. Although the citizen participants worked closely with the civil servants in the team, their ability to act was controlled and therefore limited. The platform was initiated, built and maintained by IJburg citizens meaning they did have agency over both the infrastructure, the data and most of the content.

\section{Emancipation}

The main objective of 'HalloStrandeiland.nl' was to grow a community of future residents to form collective alternatives or (sustainable and social) additions to the municipality's plans to create forms of ownership and enhance inclusiveness of the development process. The platform therefore aimed to contribute towards the emancipation of its future citizens. Although citizens were represented in these formal municipal decision-making processes through a seat on the participation team, they could only have a say on certain details within predetermined topics and not provide alternative scenarios, which means they were not fully empowered. They were recognised and valued for their contribution towards these precooked topics by both the project team and local citizens, opportunities to create space for recognition for potential additional futures and hence deepening and widening the debate on city-making were not given. Citizens could for instance suggest ideas for facilities or activities on the beach but not on a potential alternative for the beach itself. Despite the fact that the citizens did receive a reimbursement for their contribution to establish greater equality and equal availability amongst the team members, a true collaborative process in which decision-making power was equally distributed within the team did not occur: the client-customer relationship contributed towards the hierarchical attitude of the municipality, which hindered the emancipation of the engaged citizens.

\section{Homies}

Between January and March 2020, residents, local entrepreneurs, artists, social workers, designers, researchers and government officials took part in a series of three 
design-driven workshops. They co-creatively developed and tested low-fi prototypes of products and services to explore how to generate local and sustainable value and business models in the field of last mile logistics. They introduced 'Homies', an idea for a match-making platform via which youth with a distance to the labour market could execute delivery services for local entrepreneurs; offer local shopping and transport services to residents; and provide last mile logistics support to (online) shops and home delivery providers in general. Supported by youth workers, these couriers would gain experience and labour market qualifications.

\section{Engagement}

The researchers (initiators of the project) considered the relatively deprived area of Rotterdam Zuid as a place where developments concerning last mile logistics would have significant economic and social impact. Hence, they considered it essential to provide stakeholders with the opportunity to be actively involved in developing alternatives. In collaboration with a neighbourhood cooperation, they recruited a diverse group of relevant participants to a co-creative project: four residents, two local entrepreneurs, two civil servants (Digital Innovation; Mobility), four community and youth workers and two designers. With the designers, the researchers developed a process through which participants were supported to identify issues, voice their concerns, define shared values and to imagine and develop alternative futures. The facilitator laid out the ground rules of collaborative working - such as equal say, equal right of participation, trust and respect - at the beginning of the first event, enabling each at the table to voice their objectives and concerns.

During the first session, participants worked in small groups and translated their ideas and ideals regarding local last mile logistics services into low-tech conversation starters. Subsequently, these groups went out into the streets - to shops, community centers and elderly homes - to discuss their propositions - for example regarding the idea to create local, social parcel-hubs - in order to test their assumptions and to engage a larger and more diverse audience in the process as well. On the basis of collected insights, the group expressed dedication to develop sustainable alternatives of current delivery systems and to test them in a real-life context. A prototype of 'Homies', a digital platform that matches a delivery service with employment opportunities for youth with a distance to the labour market, was further developed and tested at the local market and proved a potentially feasible concept for sustainable local last-mile delivery among potential stakeholders.

\section{Empowerment}

The multi-stakeholder and design-driven process was carefully crafted to support participants to take incremental steps to develop an ability to act concerning a specific smart city development. In a series of lectures the researchers, civil servants and entrepreneurs provided knowledge on issues of datafication, last mile logistics, and sustainability to the relatively uninformed participants. Throughout the project, they were provided with coaching by design experts. The latter could be considered as empowering intermediaries. Through this process, participants realized and experienced how they, their neighbours and their neighbourhood were affected 
by developments concerning last mile logistics. At the same time, the design process invited and challenged them to collectively imagine, develop and test (low-fi prototypes of) local and sustainable alternatives based on their values and concerns, which appeared to be: supporting local entrepreneurs and youth and securing a liveable neighbourhood. Participants drafted schemes in which data and value streams of the 'Homies'-platform were plotted, which helped them to come up with ideas for how the neighbourhood cooperation and its community of youth workers could function as a trusted party to own and store the data generated by the platform; to curate which data would be collected, to whom it would be made available, and under what conditions; and to distribute the value generated by the platform based on criteria that would be agreed upon by the community. Although participants figured that 'Homies' could not compete with global delivery companies on price, they concluded that it constituted an imaginary of how a small-scale cooperative logistics platform could generate local value and could contribute to shifting power relations. However, despite the fact that they participated as proposers, co-creators, decision-makers, and leaders in this workshop-context, this does not necessarily equals meaningful empowerment in further stages of developing local sustainable last mile logistics services.

\section{Emancipation}

The researchers and members of the neighbourhood cooperation actively reached out to specific people in their networks in order to have a diverse and relevant group of stakeholders that represented the various voices of those that are actually affected by smart city developments at the table: shop owners who experience that neighbours increasingly buy goods and services from web shops; neighbours that experience vacant shops in their streets; social workers that are confronted with youth with an increasing distance to the labour market; government officials tasked to make last mile logistics emission free by 2025 . We constructed the process in such a way - amongst other things through professional guidance of a facilitator - that equal say, equal right of participation, trust and respect were safeguarded: an atmosphere was created in which all participants could contribute in their own capacity and in ways they found relevant and in which their contributions were valued. Participants were provided with a financial compensation to free up their time for this project, which could be considered a form of redistribution and which contributed towards the feeling of being an equal and valued member of the group (interview citizen participant).

In line with the 'Right to the Smart City's aim to include individuals and groups that are, through traditional processes, largely left out of participation in urban development processes, the 'Homies' platform was designed to challenge dominant power structures: youth with a distance to the labour market would not only receive a wage, but would also gain work experience, skills and certificates (Open Badges) while being closely guided by a job coach as a local alternative to the seemingly inevitable and daunting gig economy. Again: although this process was designed as an emancipatory process, it is no guarantee that it would overcome power imbalances in further, more concrete stages of local and sustainable last mile logistics services. 


\section{Rotterdam Digitaal}

In April 2020, informed by a report of a consultancy agency (KPMG, 220a), the municipality of Rotterdam invited two Rotterdam-based digital design agencies to develop a prototype of a data-driven retail platform to invite and support retailers to join forces to come up with local and sustainable propositions to face the challenges of both the emerging platform economy and the present COVID-crisis. An alderman challenged the team of three CEO's, two project managers, two UX-designers, three developers, two communications specialists, one consultant, four civil servants and two researchers to present a first version of a platform within 6 weeks.

\section{Engagement}

According to KPMG's and the municipality's analyses, a local data-driven platform would be essential to support retailers struggling with decreasing revenues due to increases in online shopping. Although research by the municipality indicates that $60 \%$ of the retailers in Rotterdam are hardly using any digital means of communicating, organizing and marketing, this part of the target audience was hardly involved in the development process. Due to decisions concerning time and budget allocation, efforts to engage the stakeholder population in the process were limited to a small series of interviews with retailers (10) and government officials (2) in the networks of the designers and the researchers, and additional online research to determine what type of interactive platform would suit retailers' and their customers' current and future needs. Strikingly, the potential stakeholders that were approached would not necessarily consider a platform as the most effective means to address their most pressing needs and concerns, such as increasing revenue and maintaining a safe and pleasant shopping environment. Besides that, most of the retailers interviewed did not express a strong motivation or willingness to be involved in a digital platform and the design thereof, because, based on previous campaigns of the municipality, most of them did not expect to benefit from them. Nonetheless, members of the project team (designers, developers and researchers) engaged in a design sprint, i.e., they followed a strict - not necessarily open - programme of predetermined activities to co-creatively set the parameters and to actually prototype and test a first version of the platform within 1 week. The sprint resulted in "rotterdamdigitaal.net." On this website retailers could share and learn from each other's experiences, questions, concerns and ideas, and they could team up, pool resources and apply for funding to develop meaningful, innovative (digital and data-driven) solutions and fruitful business cases regarding the challenges they face. Since the strict format and short timeframe had left little room for open deliberation and contemplation among the experts involved, nor for structural involvement of the target audience in this process, the basic idea behind this platform was mainly based on the municipality's, consultant's, designers', developers' and researchers', and not on its potential users' assumptions, objectives, values and concerns.

\section{Empowerment}

Although a design sprint is meant to create equal partnership between the participants, the designers and researchers (as autonomous empowering intermediaries) decided upon the contents of the platform, and the civil servant who represented the 
municipality of Rotterdam (and the client who ordered the platform), rather than members of the actual target audience, had final decision-making power concerning the direction the design of the platform would take. In the philosophy of the consultancy, the government officials and the CEOs of the design agencies, activity on the platform would be boosted as the first projects on the platform would be initiated by these very design agencies themselves, or by their affiliated communication agency and the members of their networks who signed a 'Letter of Support.' However, in the first year since it was launched, no initiative was posted at rotterdamdigitaal.net. Probably this is because the potential users of the platform were not engaged in, nor felt entitled to any decisionmaking power in the development of Rotterdam Digitaal. Hence it does not contribute to their empowerment with regard to the platform economy.

The municipality explicitly considers itself ultimately as the facilitator rather than the owner of the platform. Its ambition for 'Rotterdam Digitaal' is that it becomes an autonomous, self-sustaining entity, governed by stakeholders, which sustains itself in the coming years. This means that Rotterdam imagines that it will have a seat in the steering committee, but with no more decision-making power than any other member of that committee. The question is how its intended withdrawal would make room for citizens and local entrepreneurs - and especially the non-usual suspects - to have actual decision-making power, ownership and control regarding the platform and hence regarding practices of digitization and datafication in Rotterdam.

\section{Emancipation}

In its 'Action Agenda' (Rotterdam 2020), the Rotterdam council emphasizes its concern for inclusiveness. It states that 'Rotterdam Digitaal' should be the result of a co-creative process including citizens, entrepreneurs, civic society, knowledge institutions and other partners, aiming to provide entrepreneurs with the opportunities to develop innovations, while, at the same time, "the rights and interests of the people of Rotterdam are protected, so that everyone can benefit, and no one is left behind." However, the promise of the government officials to present the alderman with concrete results within limited time outweighed solid and inclusive, co-creative research. Although we, as researchers, considered this 'under-representation' a serious flaw in the process of granting citizens an equal and meaningful engagement and decision-making power in the development and governance of (the economic opportunities in) their city, the consultancy, the government officials and the CEO's of the design agencies held the position that, once the platform was built, and once an affiliated communication agency would have 'loaded' it with content, other Rotterdammers would gradually find their ways to the platform and benefit from it (KPMG 2020b, p. 8). By then, these experts claimed, gradually, the transition towards a decentralization of the platform's governance should be planned. Only the future can tell if and how that will turn out. For now, we must conclude that, despite the rhetoric of openness and inclusiveness, the involvement of stakeholders, and the valuation of their input in the development process was (deliberately) quite limited, and that by considering themselves as curators, those who started the project structurally violated the principles of radical inclusiveness and redistribution of resources and power. Based on the 'Letter of Support that the developers of the platform composed, we can conclude that they consider digitization and datafication as an objective, a-political, 
solutionist means and an opportunity to improve the entrepreneurial and living climate of the Rotterdammers in general, rather than leaving room for democratic deliberation and for inclusion of the voices of the minorities and the disenfranchised per default. By deliberately taking this approach and this position, the initiators, governors and executors of this project might contribute to the increase of power imbalances, rather than actively trying to overcome them.

\section{Discussion and conclusion: co-creation of digital platforms and 'Governance Beyond Participation' to support to the 'Right to the Smart City'}

Through the three cases that were discussed in this paper, and led by the concepts of engagement, empowerment and emancipation, we sought to answer the question of how to support citizens' 'Right to the Smart City'.

With regard to engagement, we found that the actual involvement of relevant stakeholders strongly depends on the active recruiting work of initiators and active participants. At 'Strandeiland,' where recruitment mostly depended on word of mouth and communication via the website, mainly 'usual suspects' got involved within the initial stages. However, in the following phases of the process a stronger emphasis was put on creating greater inclusiveness by addressing the invitation to participate to a variety of citizen groups directly. At 'Homies', the network of the neighbourhood cooperation was essential to recruit a broad variety of stakeholders. Additionally, through the activity of testing assumptions and models in the neighbourhood, the network of those involved in the project was expanded significantly. At 'Rotterdam Digitaal', time and budget constraints made that only a few stakeholders were consulted in the design phase: designers, developers, civil servants and representatives of the consultancy agency involved expressed a strong belief in their own capacity to build an attractive platform and a communication strategy that would engage citizens by itself once in existence. The platform was therefore built for citizens rather than with them. With regard to engagement we also found a variety in the opportunities offered for meaningful involvement. At 'Strandeiland' these were limited, because of the fact that the civil servants involved played a decisive role in the topics that were on the agenda. This was even more the case at 'Rotterdam Digitaal', where it was decided beforehand that the target audience would benefit from a data-driven platform, whereas, from their (limited) input, one could doubt whether such a platform would effectively address their needs and concerns. At 'Homies', on the other hand, the process was essentially designed and facilitated to be as inviting, open and iteratively as possible, in order to cater for active and meaningful participation of stakeholders in line with preconditions set by for instance Fraser (1990) and Iveson (2007).

With regard to empowerment, we found only limited opportunities for stakeholders to articulate their ideas, hopes and aspirations for alternative urban scenarios and to co-creatively contribute to their realization. Although the projects we discussed were, in theory, meant to contribute to citizen's agency, decision-making power, and to local value-creation, in practice they only did that to a certain degree. First of all, participants' ability to act, as well as stakeholders' actual decision-making power in these projects appeared to be fairly limited. In the case of 'Strandeiland', in which the municipality proved unable to operate beyond a conventional client-contractor relationship 
(presumably informed by a 'traditional' control logic), civil servants prioritized topics and demarcated clear boundaries within which citizens could operate, despite the Amsterdam municipality's ambitions to allow citizens to partake in new forms of democracy. In the 'Homies' case, participants were entitled to equal decision-making powers, involving the co-creation of a concept of a local and sustainable last-mile logistics platform, based on actual needs and values and on principles of technological sovereignty. However, the conceptual character does limit us to reflect on stakeholders' actual empowerment concerning the future real-life version of this service. Besides that, it was concluded that the 'Homies'-concept would need external financial and governmental support in order to stand a chance to run a viable alternative in the face of multinational corporations dominating the gig economy. In the case of 'Rotterdam Digitaal', developers and consultants left the design and decision-making regarding the platform and the curation of its content to experts and their assumptions, despite their ambitions to build a local alternative to the platform economy, based on stakeholders' values-based propositions. Time and budget constraints, as well as their technocratic beliefs drove the initiators to embrace this top-down approach.

With regard to emancipation, we found, in all of the three cases, that municipalities and other stakeholders involved expressed ambitions to provide citizens with equal opportunities to realize their objectives. They conveyed ideas of radical inclusion and decentralization of powers. The initiators and facilitators in 'Homies' played an active role in safeguarding principles of representation and recognition by crafting a process that leveled the playing field among participants. In that same project, the neighborhood cooperation and the researchers involved actively reached out to minorities and disenfranchised people, contributing to and drawing upon their (local) knowledge base and literacy regarding the topic. A similar intention of creating inclusiveness formed an important pillar of the Strandeiland case, although this did unfortunately not reach its full potential as the before-mentioned 'usual suspects' dominated the process of citymaking in the first operational year. And whereas the dominant players of 'Rotterdam Digitaal' - potentially due to political ambitions, budget and time constraints and technocratic beliefs - put their hope on a trickle-down effect - presuming that minorities, disenfranchised and lesser-active stakeholders would eventually learn and benefit from the pioneering work of experts, elites and more-active peers - we found no proof of that. In fact, it could just as well be that failing to actively include 'unusual suspects', minorities and disenfranchised at the early stages of a city-making process would negatively impact their opportunities regarding equal participation and being valued for their efforts. With regard to redistribution, we found that the participants in 'Strandeiland' and 'Homies' appreciated the compensation for their contribution, which made them feel valued. In the 'Rotterdam Digitaal' case, however, the fact that designers, developers and consultants were generously compensated, while researchers and stakeholders (local retailers) were not, might have contributed to a situation in which the idea of carrying out a straightforward commercial assignment might have prevailed over taking on the complex task of emancipating seemingly unknown stakeholders.

We thus conclude that supporting citizens' 'Right to the Smart City' demands carefully designed, facilitated, curated and managed processes in which initiators or staff (empowering intermediaries) have an active engagement and in which the aspects of 
engagement, empowerment and emancipation are systematically and structurally (but openly and iteratively) explored and addressed (Sennett 2013). From the 'Homies' case we learnt that an already-existing local network could play an essential role in that. We also learnt that time and budget constraints, technocratic beliefs, as well as established - traditional - and imbalanced power relationships and divergent views, concerns and objectives among stakeholders could lead to less sustainable instances of addressing issues of engagement, empowerment and emancipation. Our research indicates that pragmatical, incidental and superficial use of the rhetoric of citizencentricness could potentially lead to tokenism and a situation in which participants become, purposely or accidentally, part of the established system, which generally prevents them to fully exercise their 'Right to the City' (cf., Mayer 2013).

In the discourse on the 'Right to the Smart City', it is emphasized that a city's inhabitants should be in a position to actively articulate and effectuate their concerns, views and aspirations. Besides that, they should have ample and equal opportunities to generate value for themselves and their communities. From the three cases we studied it appeared that the process of co-creating a digital platform did not in itself provide 'ordinary' citizens with a genuine opportunity to sustainably reimagine and remake the smart city based on their actual - political - hopes and aspirations for their future city lives for no other reasons than why it generally is complicated to enable citizens' 'Right to the City:' power struggles in complex and political urban landscapes. Hence, we conclude that, in order to truly support citizens' Right to the Smart City, not only active and motivated citizens willing to participate in processes of engagement, empowerment and emancipation, are needed but, moreover, that the open, flexible and transparent forms of governance that Sennett $(2013,2018)$ refers to could potentially positively contribute to that. To support such types of governance, institutional reforms are needed, in which citizens are considered as equal, responsible and trustworthy participants in the public sphere. Hence, we advocate new roles and responsibilities for both government and citizens. In smart city development processes, there must be room for cooperation, but, at the same time, countervailing powers should be perceived as an enrichment, rather than a nuisance in the democratic act smart of city-making. In short, it is time for 'Governance Beyond Participation;' for city-making processes where citizens are valued as trustworthy collaborators in a decisionmaking capacity.

Acknowledgements

The authors thank all the participants of the Data Empowerment Design Studios of Afrikaanderwijk, Strandeiland and Rotterdam Digitaal.

\section{Authors' contributions}

Els Leclercq: Conceptualization, Methodology, Investigation, Writing- Original draft preparation, Visualization, Investigation, Writing- Reviewing and Editing; Emiel Rijshouwer: Conceptualization, Methodology, Investigation, Writing- Original draft preparation, Visualization, Investigation, Writing- Reviewing and Editing. The author(s) read and approved the final manuscript.

\section{Authors' information}

Els Leclercq is a researcher at Delft University of Technology and Amsterdam Institute for Advanced Metropolitan Solutions, The Netherlands. She conducts research on topics related to the transition towards a sustainable urban environment including circular economy, digitalization ('smart city'), new democracy and citizen engagement. Her PhD dissertation, prepared at Delft University of Technology, focused on the privatization of public space in European cities. Emiel Rijshouwer is a researcher in the Department of Public Administration and Sociology at Erasmus University Rotterdam. His research concerns online and offline self-organization and citizen participation in urban challenges. As an affiliate of the Leiden-Delft-Erasmus Centre for BOLD (Big Open and Linked Data) Cities he is involved in design-driven research concerning citizen engagement and empowerment regarding the datafication of public space. 


\section{Funding}

This research was conducted with financial support from Delft University of Technology, Erasmus University Rotterdam, AMS institute Amsterdam, Nederlandse organisatie voor Wetenschappelijk Onderzoek.

\section{Availability of data and materials}

Data and materials (transcripts of interviews and imagery) are available on request.

\section{Declarations}

\section{Competing interests}

The authors declare they have no known competing financial interests that could have influenced the work reported in this paper.

\section{Author details}

${ }^{1}$ Faculty of Architecture and the Built Environment, TU Delft, Delft, The Netherlands. ${ }^{2}$ Erasmus School for Social and Behavioral Sciences, Department of Sociology, Erasmus University Rotterdam, Rotterdam, The Netherlands.

Received: 8 December 2020 Accepted: 14 February 2022

Published online: 07 March 2022

\section{References}

Amsterdam (2019). Participatieplan Strandeiland 2019-2020

Anastasiu I. Unpacking the smart city through the lens of the Right to the City: a taxonomy as a way forward in participatory city-making. In: de Lange M, de Waal M, editors. The hackable city: Springer; 2019. p. 239-60.

Arnstein S. A ladder of citizen participation. J Am Inst Plann. 1969;35(4):216-24.

Baack S. Datafication and empowerment: how the open data movement re-articulates notions of democracy, participation, and journalism. Big Data Soc. 2015;2015:1-11.

Bass T, Old R, editors. Common knowledge: citizen-led data governance for better cities: DECODE; 2020.

Beaulieu R. Action research: trends and variations. Can J Action Res. 2013;14(3):29-39.

Bekkers V, Tummers L. Innovation in the public sector: towards an open and collaborative approach. Int Rev Adm Sci. 2018;84(2):209-13.

Bria F. Public policies for digital sovereignty. In: Scholz T, Schneider N, editors. Ours to hack and to own. The rise of platform cooperativism, a new vision for the future of work and a fairer internet: OR Books; 2016. p. 218-22.

Cardullo P. Smart commons or a "smart approach" to the commons? In: Cardullo P, Di Feliciantonio C, Kitchin R, editors. The Right to the smart city: Emerald Publishing Limited; 2019. p. 1-24.

Cardullo P, Di Feliciantonio C, Kitchin R, editors. The right to the smart city: Emerald Publishing Limited; 2019.

Cardullo P, Kitchin R. Being a 'citizen' in the smart city: up and down the scaffold of smart citizen participation in Dublin, Ireland. GeoJournal. 2018:84:1-13.

Cowley R, Joss S, Dayot Y. The smart city and its publics: insights from across six UK cities. Urban Res Pract. 2018;11(1):53-77.

De Waal M. The ideas and ideals in urban media. In: Foth M, Forlano L, Satchell C, Gibbs M, editors. From social butterfly to engaged citizen: urban informatics, social media, ubiquitous computing, and mobile technology to support citizen engagement: MIT Press; 2011. p. 5-20.

De Waal M, De Lange M, Bouw M. The hackable city: citymaking in a platform society. Archit Des. 2017;87(1):50-7.

Dorst K. Design beyond design. She Ji. 2019;5(2):117-27.

Engelbert J, Van Zoonen L, Hirzalla F. Excluding citizens from the European smart city: the discourse practices of pursuing and granting smartness. Technol Forecast Soc Chang. 2019:142:347-53.

Fainstein S. The just city: Cornell University Press; 2011.

Foth M. Some thoughts on digital placemaking. In: Hausler MH, Tomitsch L, Hespanhol L, Tscherteu G, editors. Media architecture compendium: digital placemaking: AVEdition; 2017. p. 203-5.

Foth M, Brynskov M. Participatory action research for civic engagement. In: Gordon E, Mihailidis P, editors. Civic media: technology, design, practice: MIT Press; 2016. p. 563-80.

Fraser N. Rethinking the public sphere: a contribution to the critique of actually existing democracy. Soc Text. 1990;25(26):55-80.

Fraser N. Mapping the feminist imagination: from redistribution to recognition to representation. Constellations. 2005;12(3):295-307

Fung A, Wright E. Deepening democracy: innovations in empowered participatory governance. Polit Soc. 2001;29(1):5-41.

Greenwood D, Levin M. Introduction to action research. Social research for social change: Sage Publications; 2007. Harvey D. The right to the city. New Left Rev. 2008;53:23-40.

Iveson K. Publics and the city: Wiley Publishers; 2007.

Iveson K. Cities within the city: do-it-yourself urbanism and the Right to the City. Int J Urban Reg Res. 2013;37(3):941-56.

Jones P, Bowes J. Rendering systems visible for design: synthesis maps as constructivist design narratives. She Ji. 2017;3(3):229-48.

Kitchin R. Toward a genuinely humanizing smart urbanism. In: Cardullo P, Di Feliciantonio C, Kitchin R, editors. The right to the smart city: Emerald Publishing Limited; 2019. p. 193-204.

Kitchin R, Cardullo P, Di Feliciantonio C. Citizenship, justice, and the right to the smart city. In: Cardullo P, Di Feliciantonio C, Kitchin R, editors. The right to the smart city: Emerald Publishing Limited; 2019. p. 1-24. 
KPMG (2020a). Handelingsperspectieven voor de Platformeconomie. 30 March 2020.

KPMG (2020b). Rotterdam Digitaal Governance \& Organisatie, CONCEPT Versie 0.1, 1 July 2020

Kuitert L. The balancing act - How public construction clients safeguard public values in a changing construction industry. TU Delft Open: Doctoral dissertation, Delft University of Technology; 2021.

Lam D, Martín-López B, Wiek A, Bennett E, Frantzeskaki N, Horcea-Milcu A, et al. Scaling the impact of sustainability initiatives: a typology of amplification processes. Urban Transformations. 2020;2(3):1-24. Lefebvre H. Writings on cities: Blackwell; 1996 [1968].

Loorbach D, Frantzeskaki N, Avelino F. Sustainability transitions research: transforming science and practice for societal change. Annu Rev Environ Resour. 2017;42:599-626.

Marcuse P. Whose right(s) to what city. In: Brenner N, Marcuse P, Mayer M, editors. Cities for people not for profit: critical urban theory and the right to the city: Routledge; 2012. p. 24-41.

Martin C, Evans J, Karvonen A. Smart and sustainable? Five tensions in the visions and practices of the smart-sustainable city in Europe and North America. Technol Forecast Soc Chang. 2018;133:269-78.

Mayer M. First world urban activism - beyond austerity urbanism and creative city politics. City. 2013;17(1):5-19.

Morozov E, Bria F. Rethinking the smart city: The Rosa Luxemburg Stiftung; 2018.

Mulder I, Kun P. Hacking, making, and prototyping for social change. In: de Lange M, de Waal M, editors. The hackable city: Springer; 2019. p. 225-38.

Mulder I, Loorbach D. Rethinking design: a critical perspective to embrace societal challenges. In: Kossoff G, Potts R, editors. Can design catalyse the great transition: papers from the transition design symposium 2016: Carnegie Mellon University; 2018. p. 16-24.

Pentland A. Social physics. How good ideas spread - the lessons from a new science: Penguin; 2014.

Razsa M, Kurnik A. The occupy movement in ŽiŽek's hometown: direct democracy and a politics of becoming. Am Ethnol. 2012;39(2):238-58.

Rotterdam (2020). Aanzet actieagenda Rotterdam Digitaal (Concept 08-04-2020).

ScholzT, Schneider N, editors. Ours to hack and to own. The rise of platform cooperativism, a new vision for the future of work and a fairer internet: OR Books; 2016.

Sennett R. The open city: Youtube; 2013. https://www.youtube.com/watch?v=eEx1apBAS9A\&t=2032s

Sennett R. Building and dwelling. Ethics for the city: Farrar, Straus and Giroux; 2018.

Shelton T, Lodato T. Actually existing smart citizens. City. 2019;23(1):35-52.

Soja E. Seeking spatial justice: University of Minnesota Press; 2010.

Vanolo A. Smartmentality: the smart city as disciplinary strategy. Urban Stud. 2014;51(5):883-98.

Wilcox D. The guide to effective participation: Partnership; 1994.

Wittmayer J, Schäpke N. Action, research and participation: roles of researchers in sustainability transitions. Sustain Sci. 2013;2014(9):483-96.

Zuboff S. The age of surveillance capitalism: the fight for a human future at the new frontier of power: Public Affairs; 2019.

\section{Publisher's Note}

Springer Nature remains neutral with regard to jurisdictional claims in published maps and institutional affiliations.

- fast, convenient online submission

- thorough peer review by experienced researchers in your field

- rapid publication on acceptance

- support for research data, including large and complex data types

- gold Open Access which fosters wider collaboration and increased citations

- maximum visibility for your research: over $100 \mathrm{M}$ website views per year

At BMC, research is always in progress.

Learn more biomedcentral.com/submissions 